\title{
COVID-19 Impact on International Migration
}

\author{
Ihab S KH Jweida ${ }^{1}$
}

\begin{abstract}
COVID 19 created many problems around the world and it affected everybody including migrants and immigrants. Many countries halted asylum seeker procedure in order to stop COVID 19 spreading but some countries restarted asylum seeker procedure since many people were in dangerous situation and they needed protection. Migrants and immigrants are highly vulnerable and can be infect by COVID 19. Many organizations especially international Organization played and are playing very important role to protect them against COVID 19. Migrants are working in frontline, they are in contact with other people, and the risks are very high to infect by COVID 19. Many of them hit globally very hard because of the COVID 19 especially due to the economic shut downs for example food, accommodating and personal services. Many countries closed their borders and they halted asylum seeker procedure. The number of restrictions and measures that imposed on migrants and immigrants reached 4600 around the world. Many countries have imposed travel ban especially on new comers.
\end{abstract}

Keywords: COV ID 19, Migrant, Immigrant, Restrictions, International Organizations.

JEL Classification: F22, J60

DOI: $10.24818 / \mathrm{REJ} / 2021 / 82 / 10$

\section{Introduction}

COVID 19 has caused to halt migration of people around the world. Some countries paid more attention because of human rights and they restart the procedure of refugees and asylum seekers. However, we will discuss more related to this subject below and the countries that did not stop their support to asylum seekers and refugees. EU and the US halt the asylum seekers and refugees programs for a while but they restarted it because many people stranded in dangerous situations. The virus could harm refugees very badly because they are highly vulnerable to infections and the consequences could be disastrous. International organizations (United Nation High Commission, International Organization for Migration, and World Health Organization) played important

1 Bucharest University of Economic Studies, Bucharest Romania, e-mail: ihab_emperor @yahoo.com 
rule to provide guidance on how to make-sure human rights protections for those displaced migrants that are living in the refugee camps or outside a camp.

These structures put in action as humanitarian actors on the field answer to erupt in camps and other places that migrants are living. Hence, most of the guidance are focusing on indirect assumption such as water, hygiene, medical services, safety infrastructure and sanitation. Most of these services are limited, the people that are living in the camps do not respect social distance measures, and it makes it more difficult to respond COVID 19 measures.

COVID 19 measures are not very favorable for displaced migrants outside the camps especially for those people that displaced and are moving from one area to another. Most of migrants do not have direct access to health care in host countries and they create serious issues for broader society. Some countries made it easier for documented and undocumented migration to benefit from direct health services. It is important to mention that in most countries migrants do not have access to health services even during pandemic. COVID 19 made it more difficult for displaced migrants to have a safe accommodation and many of them may remain homeless.

A topic at the center of displaced migration is the legal rule, which illustrate immigration process. Due to the COVID 19 epidemic, many restrictions imposed on travel and created more issues in order to implement migration procedure such as detention orders, deportation, and migration detention extend especially inside the countries. Host countries decided to halt deportation; they released detained migrants, and extend their residence documents. Unfortunately, many countries did not respect above-mentioned issues and they are not compliance with international law.

Migrants job are retail and wholesale and they are in frontline because they are in contact with other people and became vulnerable, it means they are at higher risks to infect by COVID 19. Migrants are hit globally very hard because of the COVID 19 especially because of the economic shut downs for example food, accommodating and personal services. Due to bureaucratic barriers, many qualified migrants forced to work in other fields with lower income.

In this article, I took an international perspective in practicing policies matter to explain the effect of COVID 19 for refugees and migrants, especially due to the closing border issues and journey restrictions. Many countries are not making any exception for asylum seekers, however, World Health Organization already provided them information and guidance related to quarantines and health screening measures. In refugee camps and accommodation places for migrants, 
COVID19 restrictions and recommendations are not respected and many people are living in the same room.

The Introduction section should refer to the context of the research. Introduction states the objectives of the work and provides an adequate background, avoiding a detailed literature survey or a summary of the results.

\section{Reintroducing Border Controls}

In order to control COVID 19 spreading, countries around the world imposed different border control measures. Various measures imposed such as restriction on travelling abroad or from abroad to the country and some countries closed their borders. Because these measures many migrants, who were working in Romania and other countries affected.

\section{Imposed Travel Restriction}

In 09.04.2020, countries around the world imposed 4600 restrictions and measures to stop COVID 19. Almost all international borders shut down for unnecessary arrivals / travels and only important and necessary travels allowed to enter the country. Even inside the countries, travel restrictions imposed.

Table 1. Exception and Travel Ban around the world in 2020

\begin{tabular}{|l|l|}
\hline \multicolumn{2}{|c|}{ Most Common Restriction Measures } \\
\hline $\begin{array}{l}\text { Entry restrictions for passengers from } \\
\text { restricted countries/territories/areas }\end{array}$ & 38,293 restrictions \\
\hline Medical requirements (such as quarantine) & 5,738 restrictions \\
\hline $\begin{array}{l}\text { Visa requirements/arrangements changed } \\
\text { Restricted nationality }\end{array}$ & 422 restrictions \\
\hline Other & 299 restrictions \\
\hline \multicolumn{2}{|c|}{ Key Travel Restriction Exceptions } \\
\hline Nationals (including family) & 97 Countries/Territories/Areas \\
\hline Residents (including family) & 82 Countries/Territories/Areas \\
\hline Humanitarian workers & 36 Countries/Territories/Areas \\
\hline Healthcare workers & 22 Countries/Territories/Areas \\
\hline Those in need of urgent medical treatment & 12 Countries/Territories/Areas \\
\hline Cross-border workers & 7 Countries/Territories/Areas \\
\hline Other & 56 Countries/Territories/Areas \\
\hline
\end{tabular}

Source: https://voxeu.org/article/covid-19-immigrant-workers-europe 
Figure 1. Migrants share among key workers in the EU countries

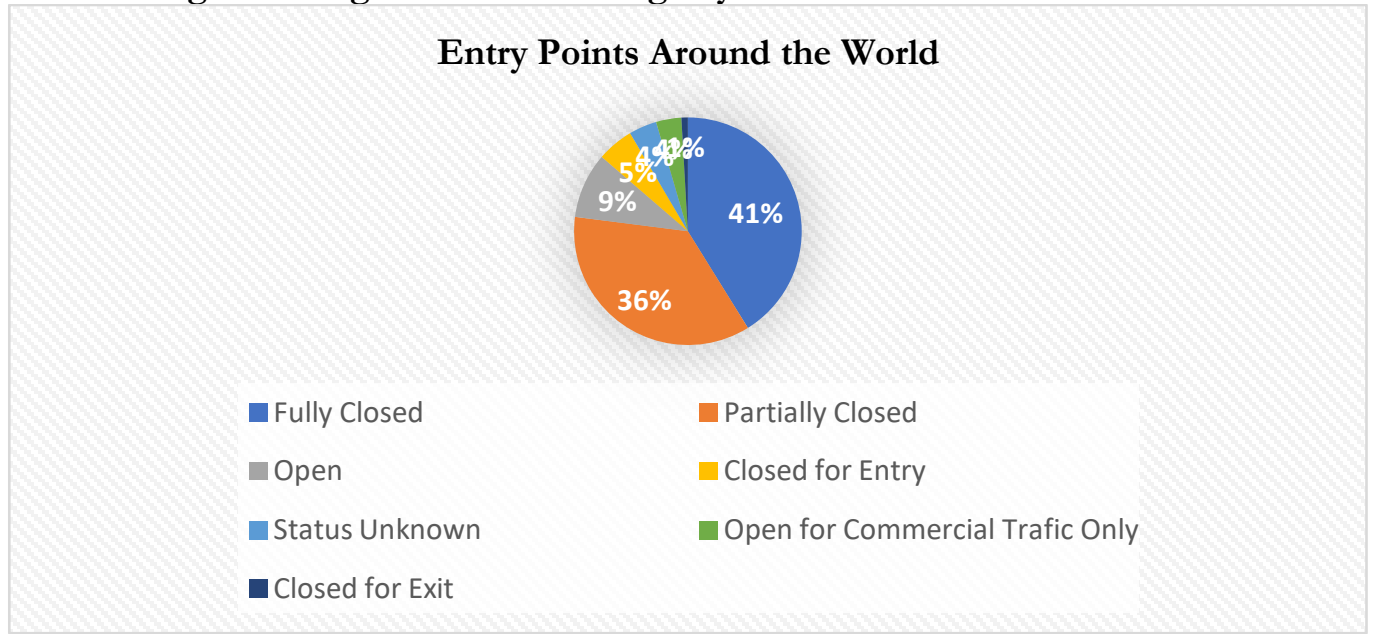

Source: Analysis of IOM’s publication, Global Mobility Restriction Overview, April, 2020

\section{Guidance and Policy in the EU}

On 17.03.2020, the European Council and the European Commission agreed to impose restriction on unnecessary travels for 30 days to the European Union. All European countries agreed and applied this measure, but COVID 19 was spreading in the EU and the restriction extended until 15.05.2020. The border control forces guided to allow their citizens that were living abroad and to make sure movement of workers between the union countries.

Border control restrictions was not affecting EU citizen and foreigners with longterm residence. The EU countries agreed not to impose restriction on necessary staff (such as medical goods, doctors and nurses' movements, agricultural workers, researchers and so on.). EU member states allowed to refuse non-EU citizens entry from abroad especially those people with symptoms of COVID 19.

\section{COVID 19 in Europe: Restrictions and key migrants}

In order to slow down spreading of COVID 19 and providing enough time to health sector to take care of those citizens that are affected seriously, many European countries shut down their economies. This shutdown forced many migrants and other workers to stay at home but there was a need to keep open the hospitals to treat the citizens and the stores to provide food for them. Key workers were doing their jobs in Europe's front line against COVID 19; migrants were essential factor in this fight. It is important to know, who these key migrants and workers are and under which circumstances they can cope with the pandemic 
because their essential services is a crucial element. There was a big concern related to key workers whether they belong to a specific group that can be vulnerable during the pandemic. Lockdown impact can be different on each group of migrants and workers based on their employment before COVID 19. Created economic impact due to the COVID 19 vary by gender, company's size, age, type of contract, employment and so on. Migrants are more vulnerable than native workers are and they can affected due to the downturns of the economy.

Based on my estimation 30 percent of workforce in the EU are migrants but this estimation varies between EU countries for example the highest percentage of migrants that is 40 percent, are working in France and the lowest is in Romania which is under 10 percent. Below (figure 1) demonstrates huge variation among EU states. In Romania, Bulgaria, Slovakia and Poland the share of migrant key workers is almost zero, in other countries such as Germany, Sweden, Austria the percentage is 20 percent. Largest percentage (53 percent) of key migrants are in Luxembourger.

Figure 2. Migrants share among key workers in the EU countries

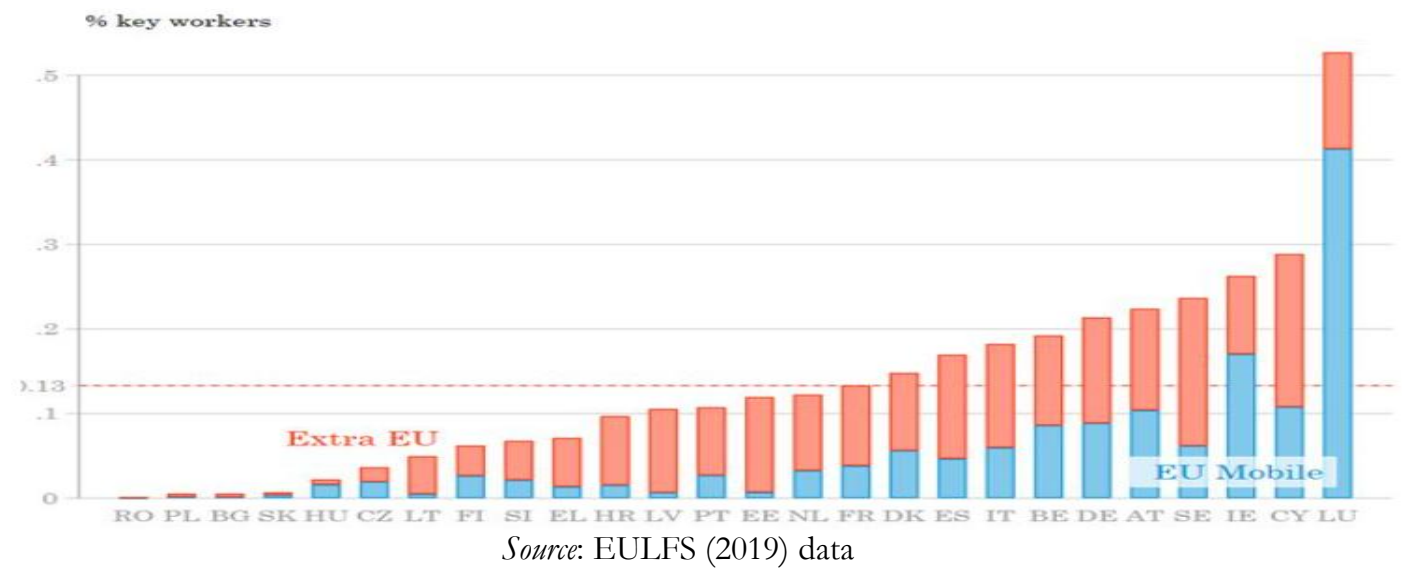

There is a substantial fraction of variation between member states in share of migrants' residence and their participation in economic activities. Below in figure 2 , there is a caparison between share of migrants among key workers in blue bars to the share of migrants in workers overall. The Extra EU workers that indicated with the dots have tendency to lie below the bars, they are overrepresented among key workers comparable to their prevalence in total numbers of workers. The biggest difference observed in Cyprus, but there is a large gap in those countries that are receiving more migrants such as Germany, Italy and Sweden. Czech Republic, Slovenia, and Croatia have low share of migrants. 
Figure 3. Migrant workers vs key migrants

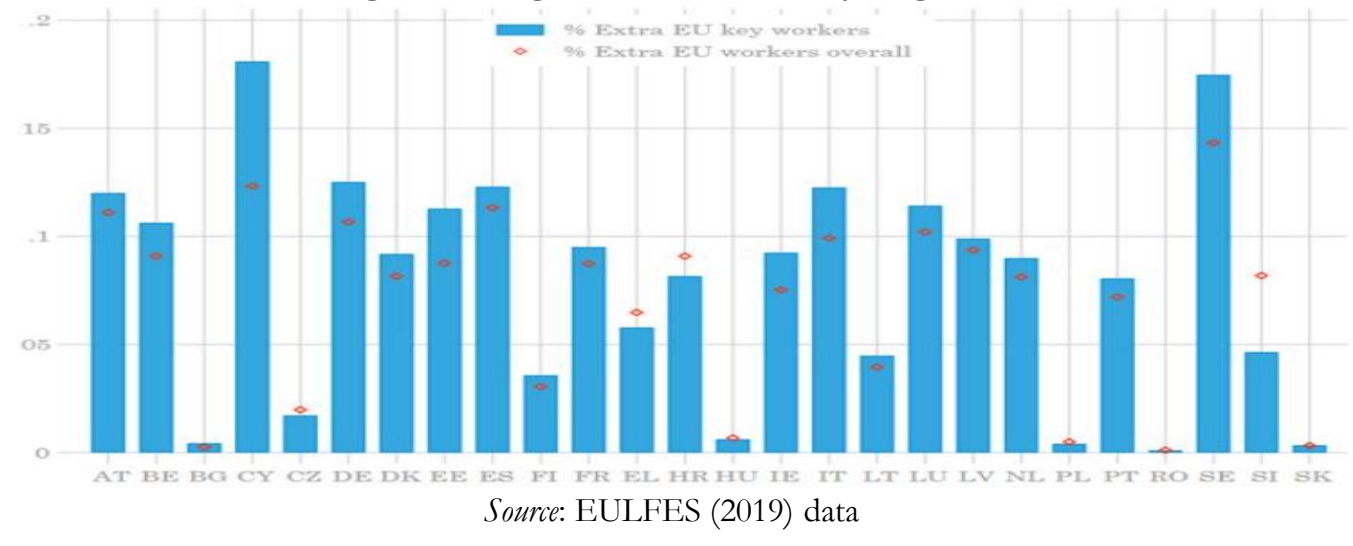

\section{Migrants and asylum seekers protections during the COVID 19}

The EU commission has provided clear guidance for the member states but some countries did not pay attention to this guidance and they impose their own restrictions and shutdown their borders. The European Union Charter of Fundamental Rights binds all member states and this oblige member states to respect and protect migrants and asylum seekers rights. It means everybody has right to ask for protection and members states must provide them protections, if member states are refusing to provide them protection, it means they are acting against European Union law and international law. EU guideline is very clear, which is saying that temporary travel ban should not affect people with need, including migrants and asylum seekers. Some countries of the EU found quality by the European Court of Justice, and these countries are not respecting their responsibilities toward asylum seekers.

\section{Workforce and Economic Considerations}

The COVID 19 created numerous workforce and economic problems around the world and these issues are affecting directly migrant integration in the labor force. Problems related to migrants can divided in two sections: a) discover talent of skilled migrants and b) the extreme representation of migrants in those jobs that are in frontline (that are in contact with people directly).

\section{Discover Talent of Skilled Immigrants in Medical Domain}

Before to the pandemic, the United States of America was facing a shortage of medical staff around the country. Based on Association of American Medical 
College research, in 2019 there was a shortage of 40010 - 122100 of physicians and in 2020, the shortage of doctors was $29100-43000$. The US is not the only country that experiencing the shortage of medical staff, other countries around the world facing the same problem, for example in 2013, the shortage of healthcare workers was 7.3 million and it expected to rise to 13 million by 2035 . According to the World Health Organization report, during the COVID 19 there a shortage of 6 million nurses around the world and this shortage affected mostly Latin America, Africa and Asia.

Rich and poor countries are facing lack of healthcare workers and the impact felt clearly in each country. If a doctor will die in Africa, around 10010 people will suffer. During the pandemic in the US, 9400 healthcare workers infected in COVID 19 and 28 of them last their life in May 2020.

Due to the shortage of medical staff, Peru, Brazil, Chile, Mexico, Spain, France, Portugal and the US have relaxed their requirements for healthcare workers from abroad and for the immigrants to join the fight against COVID 19. Other countries such as UK, China and Italy called their healthcare staff out of retirement and graduated their medical students early to respond to COVID 19.

Above-mentioned issues have paved the way for migrants and refugees that have been trained in medical field in their own country and were not able to work in this field because of strict requirements in host countries. According to one research there are 264000 migrants and refugees in the US that have degree in healthcare but they are not working in healthcare field because they did not meet the requirements and they are working in other fields or they are out of work. Because of the COVID 19 and restrictions on travel many healthcare workers could not apply for visa in the US embassies around the world to go for work in the US. During the pandemic, many countries decided to bring more healthcare workers from abroad to fill the gap in their hospitals.

According to a Facebook group that is Syrian Doctors in Germany, around 14500 Syrian doctors that applied for their qualification approval and they are waiting for authorities answer. Bavaria and Saxony announced for relaxation on qualification requirements and simplification of procedure for exams. Bavaria will provide possibilities for those healthcare workers who do not have license, to work for one year in the hospitals. Around 4500 healthcare workers welcomed this announcement and they already applied to work in healthcare centers. Saxony is paving way for refugee doctors to participate in medical training courses and will provide them medical license.

The number of healthcare workers are 2 million in the UK and $12 \%$ of them are migrants that are working there. Many of them trained in their own countries and 
have work experience and they moved to the UK for job. On May 2020, the UK's General Medical Council announced that they could to add 30500 health workers as response to the pandemic. In the UK, authorities focused mainly on those doctors that they were already registered or they had license to practice and in the same-time, many refugees' doctors hired as well during 2020.

The authorities in the UK managed to bring doctors from other countries as a response for pandemic. In the same time, many refugees called to pass their English test and to play important role in the fight against COVID 19. Migrants that did not know English very well introduced to English language classes and many Romanian health workers were hired. Doctors from many countries such as Iran, Turkey, India, Pakistan, Syria, Iraq and Sudan hired and joined the NHS.

The number of healthcare workers were low in the UK and the authorities are trying to solve it. Many people in the UK do not want to become doctors because the responsibilities are very high. There are many migrants and refugees in the UK with experience in medical field but because of the bureaucratic issues, they could not join the NHS (National Health Service).

\section{Migrants in frontline of fight against COVID 19}

During pandemic, many things changed and many jobs created, such as healthcare jobs, delivery of goods and food and so on. In the same-time, some other industries hit very hard such as hotels, restaurants, bar and many more. Many migrants affected from both situations (created new jobs and industries that were shut down.) and because of the Corona Virus, economies around the world suffered and still are suffering and most migrants are playing important role in local economics. Migrants and refugees fill unskilled jobs such as construction, food supply chain, agriculture, store workers, and sanitation services.

In 2020, there were 6 million migrant workers in the US in the frontline and are working in different field (construction, healthcare services, shops and so on). The number of workers that are working in other fields (restaurants, hotels, bars and so on) in the US are 6.5 million and we can say there are 12.5 million workers in the US on the frontlines in terms of COVID 19 answer and impact. In the EU, on average 14 percent of workers are migrants.

Donald Trump has signed an act to halt the issuance of green cards for 2 months and this decision halt migration to the US. Later they announced, the ban will not apply to agriculture workers, healthcare workers because they realized that migrants are important factor of fight against COVID 19.19 percent of workers 
in the US are migrants, most of them are working in frontline essential industries, and they are making 17 percent of workforce in the US.

\section{Access to asylum}

In 2109, Donald Trump administration suspended asylum process at the southern border. Trump Administration conducted a policy (Remain in Mexico), according to this policy, the asylum seekers have to stay in Mexico and their applications were analyzed in the US. If their applications admitted, they could to enter in the US. A large number of Mexican sent to Mexico and they should wait there until their applications analyzed. During COVID 19, Canada, US and Mexico imposed restrictions on asylum seekers.

\section{Conclusions}

Policymakers can learn two lessons for this evidence. First, migrants have important role and they are playing important role in doing essential functions around the world especially in developed countries. Authorities from developed countries should intervene in the short term to help the migrants to manage with the current crisis due to the COVID 19. Second, low skilled and low educated migrants hired in jobs that are important for host countries. The migrants should be help in order to persuade them especially high skilled migrants to move in their countries.

Each year many people are searching jobs in other countries and they move to a country where she/he can find a good job. In 2020, all countries banned traveling and nobody could move in another country for a job. Due to COVID 19, many people lost their jobs, especially migrants were affected very badly, since they lost their jobs, they did have insurance, they did not have family in host country to support them, governments did help them, their visa expired and they became homeless or they moved with other people in the same room. In order to help them, authorities should provide them accommodation, extend their visa, provide them medical insurance, help them to get a job and provide them general protection.

Many countries closed their borders and asylum seekers were returned to their home countries or to those countries from where they come. Situation is very bad in asylum seekers camps especially in Greece, Serbia, Libya and other countries. They became highly vulnerable and could get COVID 19 very easily and the result could be disastrous. Luckily some countries agreed to re-open their asylum seekers centers to accept new comers and other countries should follow the same 
procedure. Asylum seeker camps should get extra help to face with COVID 19 challenges such as new rooms to keep asylum seekers separate and so on.

In 2019, many workers from different countries came to Romania for work and because of COVID 19 they lost their jobs. Some of them decided to leave illegally Romania and to go to western European Countries, some of them are trying to find another job and some of them were deported to their countries because their visa expired and they did not have legal status in Romania. Romanian authorities did not intervene to help them and the workers were left by themselves. In future migrants will not choose Romania because they will not get any support from authorities and they will go to those countries, where can get more support. COVID 19, forced many businesses to shut down in Romania for example restaurants, bars, wedding halls, construction companies and so on. Most of migrants were working in these places and now they are jobless.

\section{Acknowledgment}

I would like to express my gratitude and appreciation to all the Professors of The Bucharest University of Economic Studies, who took part in the preparation, presentation, public defense and discussion of my paper. I deeply appreciate my coordinate professor valuable recommendations, all those instructions and consultations, because without it there would not have been such a result.

I sincerely wish you all only grateful, capable and smart students and further success in your activity, of course, my deep gratitude to my scientific coordinator Prof. univ. dr. ZAHARIA RODICA for her guidance, for her help at all stages of this research. For her highly qualified and objective reviews, which made it possible to identify the shortcomings and better understand the significance of the work that I performed, as well as for the overall positive assessment of this work.

Finally, I want to dedicate this study to my family, they always gave me a positive energy and guided me during the period of my study in Romania. I hope that they will forgive and understand my absence beside them for a long period of time.

\section{References}

Adrian Humphreys, 2020, With COVID-19 clampdown, number of asylum seekers at Canada-U.S. border slows to a trickle. Available at: https://nationalpost.com/news/with-covid-19-clampdown-number-ofasylum-seekers-at-canada-u-s-border-slows-to-a-trickle

Austen Ian, 2020. In Shift, Trudeau Says Canada Will Return Asylum Seekers to U.S. Available at: https://www.nytimes.com/2020/03/20/world/canada/ trudeau-asylum-seekers-coronavirus.html 
Bolter Jessica and Chishti Muzaffar. 2020, Interlocking Set of Trump Administration Policies at the U.S.-Mexico Border Bars Virtually All from Asylum. Available at: https://www.migrationpolicy.org/article/ interlocking-set-policies-us-mexico-border-bars-virtually-all-asylum

Calimo Montoya Galvez, 2020. Only 2 migrants allowed to seek humanitarian protection under Trump's coronavirus border order. Available at: https://www.cbsnews.com/news/only-2-migrants-allowed-to-seekhumanitarian-protection-under-trumps-coronavirus-border-order/

Carretero Leslie, 2020. Belgian government is doing nothing to protect migrants from coronavirus, NGOs. Available at: https://www.infomigrants .net/en/post/23804/belgian-government-is-doing-nothing-to-protectmigrants-from-coronavirus-ngos

Daniella Burgi Palomino and Lauri Alvarez, 2020. Protecting Asylum Seekers and Migrants during a Global Pandemic. Available at: https://www.lawg.org/ protecting-asylum-seekers-migrants-during-a-global-pandemic/

Dumont Julia, 2020. Greece's Malakasa migrant camp: What life is like during the coronavirus lockdown. Available at: https://www.infomigrants.net/en/ post/24010/greece-s-malakasa-migrant-camp-what-life-is-like-during-thecoronavirus-lockdown

European Commission. 2020, European Union Coronavirus response.

European Commission. 2020, Overview of the Commission's answer. Available at: https://ec.europa.eu/info/live-work-travel-eu/coronavirus-response/ overview-commissions-response_en\#borders-and-mobility

European Commission. 2020, Travel during the coronavirus pandemic. Available at: https://ec.europa.eu/info/live-work-travel-eu/coronavirus-response/ travel-during-coronavirus-pandemic_en

European Council of the European Union. 2020, Conclusions by the President of the European Council following the video conference with members of the European Council on (Coronavirus) COVID-19. Available at: https://www.consilium.europa.eu/en/press/pressreleases/2020/03/17/c onclusions-by-the-president-of-the-european-council-following-the-videoconference-with-members-of-the-european-council-on-covid-19/

Fallon Katy, 2020. Greece: 148 refugees test positive for COVID-19, all asymptomatic. Available at: https://www.aljazeera.com/news/2020/04/ greece-148-refugees-test-positive-covid-19-asymptomatic200421134039733.html

Global Detention Project, 2020. Covid-19 Global Immigration Detention Platform. Available at: https://www.globaldetentionproject.org/covid-19immigration-detention-platform 
Human Rights Watch. 2020, Greece: Nearly 2000 New Arrivals Detained in Overcrowded, Mainland Camps. Available at: https://www.hrw.org/news/2020/03/31/greece-nearly-2000-newarrivals-detained-overcrowded-mainland-camps

International Organization for Migration. 2020, Global Mobility Restriction Overview. Available at: https://migration.iom.int/reports/dtm-covid19travel-restrictions-output

Jakob Christian, 2020. Refugees in the Corona crisis: the world becomes a fortress. Available at: https://taz.de/Fluechtlinge-in-der-CoronaKrise/!5672393/

Jordan Miriam, 2020, Appeals Court Allows "Remain in Mexico" Policy to Continue Blocking Migrants at the Border. Available at: https://www.nytimes.com/2020/03/04/us/migrants-border-remain-inmexico-mpp-court.html

Juma Map: Refugees map services, 2020. Asylum and Immigration - Coronavirus Emergency. Available at: https://coronavirus.jumamap.com/en/asilo-eimmigrazione/

Kanno Youngs Zolan and Krk Semple, 2020, Trump Cites Coronavirus as He Announces a Border Crackdown, Available at: https://www.nytimes.com/ 2020/03/20/us/politics/trump-border-coronavirus.html

Keller Vera Magali, Florian Scholer, Marco Goldoni, 2020, Not a Safe Place? Italy's Decision to Declare Its Ports Unsafe under International Maritime Law. Available at: https://verfassungsblog.de/not-a-safe-place/

Rankin Jennifer. 2020, EU court rules 3 member states broke law over refugee quotas. Available at: https://www.theguardian.com/law/2020/apr/02/eucourt-rules-three-countries-czech-republic-hungary-poland-broke-lawover-refugee-quotas

Sanderson Sanderson, 2020. Greece quarantines Ritsona migrant camp after finding 20 corona cases. Available at: https://www.infomigrants.net/ en/post/23826/greece-quarantines-ritsona-migrant-camp-after-finding20-corona-cases

Siegfried, Kristy. 2020, The Refugee Brief - 31.03.2020. Available at: https://www.unhcr.org/refugeebrief/the-refugee-brief-31-march-2020/

The UN Refugee Agency, 2020. Despite pandemic restrictions, people fleeing violence and persecution continue to seek asylum in Mexico. Available at: https://www.unhcr.org/news/briefing/2020/4/5ea7dc144/despitepandemic-restrictions-people-fleeing-violence-persecution-continue.html

Townsend Mark, 2020. Patel refuses to take children from Greek camps threatened by Covid-19. Available at: https://www.theguardian.com/ world/2020/apr/12/patel-refuses-to-take-children-from-greek-campsthreatened-by-covid-19 